\title{
Numerical Comparison of Robustness of Multimode and Multicore Fibre Sensitivity against Fibre Bending
}

Veettikazhy, Madhu; Hansen, Anders K.; Marti, Dominik; Dholakia, Kishan; Andersen, Peter E.

Link to article, DOI:

10.1109/CLEOE-EQEC.2019.8873262

Publication date:

2019

Document Version

Peer reviewed version

Link back to DTU Orbit

Citation (APA):

Veettikazhy, M., Hansen, A. K., Marti, D., Dholakia, K., \& Andersen, P. E. (2019). Numerical Comparison of Robustness of Multimode and Multicore Fibre Sensitivity against Fibre Bending. Abstract from 2019 Conference on Lasers and Electro-Optics Europe \& European Quantum Electronics Conference, Munich, Bavaria, Germany. https://doi.org/10.1109/CLEOE-EQEC.2019.8873262

\section{General rights}

Copyright and moral rights for the publications made accessible in the public portal are retained by the authors and/or other copyright owners and it is a condition of accessing publications that users recognise and abide by the legal requirements associated with these rights.

- Users may download and print one copy of any publication from the public portal for the purpose of private study or research.

- You may not further distribute the material or use it for any profit-making activity or commercial gain

- You may freely distribute the URL identifying the publication in the public portal 


\title{
Numerical Comparison of Robustness of Multimode and Multicore Fibre Sensitivity against Fibre Bending
}

\author{
Madhu Veettikazhy ${ }^{1}$, Anders K. Hansen ${ }^{2}$, Dominik Marti ${ }^{1}$, Kishan Dholakia ${ }^{3}$, Peter E. Andersen ${ }^{1}$ \\ 1. DTU Health Tech, Technical University of Denmark, Frederiksborgvej 399, 4000 Roskilde, Denmark \\ 2. DTU Fotonik, Technical University of Denmark, Frederiksborgvej 399, 4000 Roskilde, Denmark \\ 3. SUPA, School of Physics and Astronomy, University of St Andrews, St Andrews, Fife, KY16 9SS, Scotland
}

Lensless endoscopes provide means for delivery and collection of light to and from tissue without any need for additional optical elements at the fibre distal end [1]. This requires a comprehensive investigation of the optical beam propagation through the fibre, since any focussing or scanning at the sample site requires the beam to be shaped at the fibre proximal end. The beam delivery and collection must be stable towards fibre bending for an accurate imaging system. In this context, the experimental acquisition of Transformation Matrix (TM) could lead to deterministic optical propagation even in non-ideal fibre structures [2,3], although one could only rely on this method after choosing the fibre for the current purpose. Even though this model has been used previously to experimentally predict the light propagation through a straight fibre [2] and then theoretically for significantly deformed segments of multimode fibres [3], an opportunity to choose a better-suited optical fibre for the specific application is not given by the TM method. We present a numerical tool to simulate various types of optical fibre under the realistic use case of bending deformations, which in turn allows the user to choose the best optical fibre with suitable parameters for the specific application before starting the experiment.

The numerical simulations of optical field propagation through varied profiles of optical fibres were done using the finite difference beam propagation method (FDBPM), which essentially deals with solving the paraxial Helmholtz equation at different transverse planes [4]. Multimode (MM) and multicore (MC) fibres were simulated by choosing the refractive index profile accordingly. The intensity and phase profiles of the electric field before and after propagation through a MC fibre of 19 single mode cores are represented in Fig. 1 (a)-(d). The field distribution was simulated to propagate a distance of $15 \mathrm{~cm}$ through the fibre. The phase profile in Fig. 1(d) of the output electric field is solely responsible for the focusing effect after the distal end, as seen in Fig. 1 (e,f). We could, for instance, model an optical fibre to be used for lightsheet microscopy, where generating a focus at the fibre distal end is paramount.

(a)

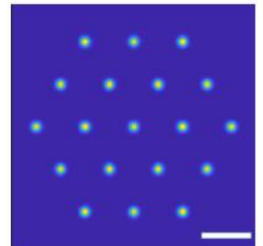

(b)

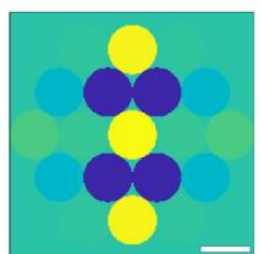

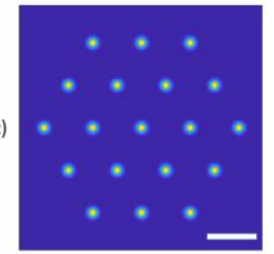

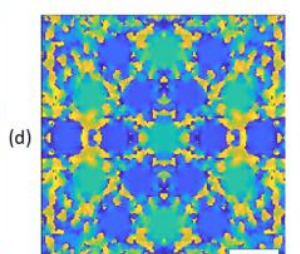

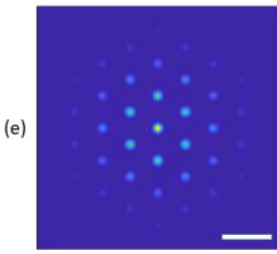

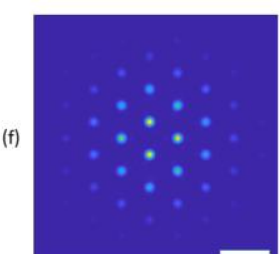

Fig. 1 (a) and (b) represent the intensity and phase of the optical field at the straight MC fibre proximal end. (c) and (d) represent the intensity and phase of the optical field at the straight MC fibre distal end. (e) represents the intensity of the optical field after focusing at a transverse plane $500 \mu \mathrm{m}$ in front of the straight MC fibre distal end. (f) represents the intensity of the optical field after focusing at a transverse plane $500 \mu \mathrm{m}$ in front of the distal end of MC, which is bent $20^{\circ}$ with bending radius of $1 \mathrm{~cm}$. Scalebars: (a)-(d) $22 \mu \mathrm{m},(\mathrm{e}, \mathrm{f}) 100 \mu \mathrm{m}$.

Although one could generate a focus at a short distance in front of the fibre distal end without any focusing optics as in Fig. 1 (e), Fig. 1(f) exemplifies that the MC fibre bent through an angle of $20^{\circ}$ with bending radius $1 \mathrm{~cm}$ does not preserve the intensity pattern at the focal plane intact as in a non-deformed fibre. At the conference, we will present results comparing the robustness against fibre bending of MM and that of MC fibres and show how this simulation tool enables the user to inherently choose an optimum optical fibre with best possible realistic parameters for any application.

\section{References}

[1] E. R. Andresen, S. Sivankutty, V. Tsvirkun, G. Bouwmans, and H. Rigneault, "Ultrathin endoscopes based on multicore fibers and adaptive optics: a status review and perspectives," J. Biomed. Opt. 21(12), 121506 (2016).

[2] M. Plöschner, V. Kollárová, Z. Dostál, J. Nylk, T. Barton-Owen, D. E. K. Ferrier, R. Chmelík, K. Dholakia, and T. Čižmár, "Multimode fbre: Light-sheet microscopy at the tip of a needle," Sci Rep. 5, 18050 (2015).

[3] M. Plöschner, T. Tyc, and T. Čižmár, "Seeing through chaos in multimode fibres," Nat Photonics 9, 529-535 (2015).

[4] Y. Chung and N. Dagli, "An Assessment of Finite Difference Beam Propagation Method," IEEE J. Quantum Electron. 26, 1335-1339 (1990). 